\title{
THE GENETIC POTENTIAL OF MOROCCAN LENTIL LANDRACES
}

\section{BENBRAHIM NADIA $^{1 *}$, GABOUN FATIMA ${ }^{2}$, MENTAG RACHID ${ }^{3}$ \& TAGHOUTI MONA ${ }^{4}$}

${ }^{I}$ Pre-Breeder, National Institute for Agricultural Research (INRA), Research Unit of Plant genetic Resources and Plant Breeding, BP 6356-Institutes 1010, Rabat - Morocco

${ }^{2}$ Bio-Informatics \& Biostatistics Researcher, National Institute for Agricultural Research (INRA, Research Unit of Biotechnology, BP 6356-Institutes 1010, Rabat - Morocco

${ }^{3}$ Biotechnologist, National Institute for Agricultural Research (INRA), Research Unit of Biotechnology, BP 6356- Institutes 1010, Rabat - Morocco

${ }^{4}$ Breeder, National Institute for Agricultural Research (INRA),Research Unit of Plant genetic Resources and Plant Breeding, BP 6356- Institutes 1010, Rabat - Morocco

\section{ABSTRACT}

Lentil landraces have been on-farm conserved in Morocco for home-consumption and for their adaptation potential to specific environment constraints. Landraces might constitute sources of optional genes of interest linked to environmental stresses resilience add to nutritional quality traits valuable for lentil crop genetic improvement. Thus, the current study aims to assess the available genetic diversity among eight lentil landraces collected from the main lentil cropped areas in Morocco by using SDS-PAGE and determinate their nutritional value compared to four improved varieties. Results evidenced the genetic richness of Moroccan's landraces according to the range of polymorphism rate (17.5\% - 80\%), allelic richness (1.100 - 1.775), expected heterozygosity(0.044 - 0.334) and Shannon-Weaver's genetic diversity Index (0.072-0.482). In addition, a large range of nutrients content variability was recorded in regards to crude proteins (26.8 - 33.8\%), total carbohydrate (46.4- 58.3\%), neutral fibers (39.7-46.4\%), lipids content (1.13-2.10 mg/100g) composed mostly of unsaturated fatty acid (83.9\%) revealing the healthy source of lentils. The major compounds of total phenols $(7.60 \mathrm{mg} / 100 \mathrm{~g})$ are the condensed tannins $(6.04 \mathrm{mg} / \mathrm{g} \mathrm{DM})$ which concentrated mainly in seed coat (67\%). The large range variability of micronutrients concentration as iron (6.57-8.26), magnesium(102.0-126.8), zinc (3.74-4.83), calcium (44.8-55.8), phosphorus(431.4-454.1), potassium (922.0-956.5) and manganese (1.27-1.37) revealed the sustainability of local genetic cores in providing rich and healthy nutrient food with high potential in developing new varieties resilient to climate change.

KEYWORDS: Lentil, Moroccan Landraces, Genetic Diversity, Nutritive Value \& Genetic Potential

Received: Mar 18, 2019; Accepted: Apr 08, 2019; Published: May 22, 2019; Paper Id.: IJASRJUN201942

\section{INTRODUCTION}

Lentil (Lens culinarisMedik.) is one of the oldest food crops that researchers have traced back to 70008000 BC in the Near East around the Fertile Crescent (Zohary, 1972; Ladizinsky, 1979; Lev-Yadun et al, (2000)). The primary center of Lens culinaris diversity was delimited at south-eastern Turkey and north-western Syria (Ferguson et al, 1998). Lentil was domesticated from the wild progenitor Lens culinaris subsp. Orientalise (Boiss.) and has spread rapidly through Mediterranean basin and central Asia (Lev-Yadun et al, 2000). Nowadays, lentil is an important seed legume crop which is cultivated worldwide for human food security. Lentil is a self-pollinating diploid species with seven pairs of chromosome $(2 x=14)$ (Arumuganathan and Earle, 1991). Lentil crop provides 
environmental and ecological services towards a sustainable farming system especially through increasing soil fertility within the atmospheric nitrogen fixation ability of the rhizobia symbiosis activity (Fenchel et al, 2012). Otherwise, local specific agro-ecological environment have generated over-time wide genetic diversity within the cultivated lentil leading to numberless of landraces (Erskine et al, 1989; Erskine, 1997). These lentil landraces have been on-farm conserved for home-consumption thanks to their nutritional and organoleptic quality add to their specific and evolutionary adaptation to local environmental constraints (Laghetti et al. 2008). Landraces have been and still the plant breeder's raw material. They have been a fruitful source of genes of interest associated to biotic or abiotic resistance, and to productivity or nutritional traits that have contributed to the green revolution in many parts of the world (Esquinas-Alcazar, (1993); Laghetti (2008)). Lentil is an important dietary source of proteins, fibers, macronutrients and micronutrients, vitamins, and antioxidant compounds (Han, (2005); Amarowics et al, (2009); Karaköy et al, (2012); Faris et al, (2013);Aslani et al, (2015);Sarker et al, (2017);Kumar et al, (2017)). Minerals play essential roles in human body as catalysts and antioxidants. Minerals malnutrition is considered to be among the most serious global challenges relevant to human nutrition and health (Kumar et al, (2016); Kumar et al, (2017); White and Broadley, (2005 and 2009). The dietary deficiency in nutrients results mostly from their low concentrations in daily diet that could have a negative effect on learning disabilities in preschool children, worker productivity, and nursing mothers and cost high health care(Yang et al., 2007). The unbalanced diet behavior and the insufficient micronutrient intake are behind the most common micronutrient deficiencies. Iron deficiency concern nearly 3.7 billion people worldwide of which 54\% are severely deficient(Yang et al., 2007). Lentil, as pulse based food might provide nutritional requirements for low incomes consumers and might be a key component of healthy diets especially in developing countries (Rehman et al, 2004; Amarowics et al, 2009).

In Morocco, lentil is produced mainly in low potential lands through the traditional farming system using landraces to insure home-consumption and livelihood security (Benbrahim et al, 2017). Seeds of lentil landraces constitute an economic dietary source of protein, essential minerals such as iron, zinc, calcium and magnesium, and antioxidant compounds (Benbrahim et al, 2016). According to Moroccan Ministry of Health surveys data (2000), the prevalence of malnutrition and micronutrient deficiency affects $37.2 \%$ of pregnant women, $31.5 \%$ of preschool aged children (6 months 5 years old), $32.6 \%$ of women of childbearing age and $18 \%$ of men. The healthcare costs and productivity losses due to micronutrient deficiencies account for about 5\% of national GDP (Aguenaou, 2007). Iron deficiency is among the most common micronutrient deficiency that affects about $50 \%$ of children aged between 7 and 9 old and $10 \%$ of women of childbearing age (Alaoui, (2005); El Menchawy et al, (2015)). Iron deficiency and anemia lead to adverse consequences on human health and productivity as the decrease of work capacity and school performance (Viteri, (1994); Alaoui, (2005); Petranovic et al, (2008)), and costs two billion dirham's per year (Aguenaou, 2007). Current rates of deficiency and anemia are mostly related to insufficient iron daily intake (Alaoui, (1991); El Hioui et al, (2007)). Plant uptake ability of iron from the soil is behind several genes expression. Specific molecular markers were developed for iron metabolism related genes and validated in lentil (Gupta et al, 2016). Thus, breeding is the appropriate suggested approach promoting healthy and nutritional status of vulnerable Moroccan people in agreement with Kumar et al, (2016). Previous studies showed that lentil cultivars provide a wide variability of nutritional quality traits (Sarker et al, 2017). The use of available genetic diversity resources among landraces enhance breeders' efficiency for crop nutritional value improvement (Hammer and Laghetti (2005); Hammer Karl and Diederichsen A. (2009)). Hence the interest of current study is to assess genetic diversity of eight Moroccan's lentil landraces using SDS-PAGE technique and determinate their nutritional value compared to four improved varieties. 


\section{MATERIALS AND METHODS}

\section{Genetic Material}

Eight lentil landraces were collected from the main lentil cropped areas in Morocco (Table 1).

Table 1: Seeds Size, Geographic Localization and Means Climatic Parameters of Studied Moroccan's Landraces

\begin{tabular}{|l|l|c|c|c|c|c|c|}
\hline \multicolumn{1}{|c|}{ Site } & ID & Latitude & Longitude & $\begin{array}{c}\text { Altitude } \\
(\mathbf{m})\end{array}$ & $\begin{array}{c}\text { Mean } \\
\text { tmperature } \\
\left({ }^{\circ} \mathbf{C}\right)\end{array}$ & Tmin - Tmax & $\begin{array}{c}\text { Rainfall } \\
\text { ( mm) }\end{array}$ \\
\hline ZAER & ZAER & $33^{\circ} 32^{\prime} 00^{\prime \prime} \mathrm{N}$ & $6^{\circ} 36^{\prime} 00^{\prime \prime} \mathrm{W}$ & 306 & 19.5 & $16.5-22.6$ & 267 \\
TETOUAN & TET & $35^{\circ} 34^{\prime} 42^{\prime \prime} \mathrm{N}$ & $5^{\circ} 22^{\prime} 06^{\prime \prime} \mathrm{W}$ & 121 & 17.3 & $13.9-20.6$ & 281 \\
RHAMNA & RHM & $32^{\circ} 14^{\prime} 00^{\prime \prime} \mathrm{N}$ & $7^{\circ} 57^{\prime} 00^{\prime \prime} \mathrm{W}$ & 449 & 20.2 & $16.0-24.2$ & 118 \\
LARACH & LCH & $35^{\circ} 11^{\prime} 35^{\prime \prime} \mathrm{N}$ & $6^{\circ} 09^{\prime} 20^{\prime \prime} \mathrm{W}$ & 38 & 18.8 & $16.6-20.9$ & 419 \\
BENI MELLAL & BM & $31^{\circ} 57^{\prime} 51^{\prime \prime} \mathrm{N}$ & $6^{\circ} 34^{\prime} 27^{\prime \prime} \mathrm{W}$ & 1351 & 18.3 & $12.4-24.3$ & 183 \\
MOULEY BOUSELHAM & MBS & $3^{\circ} 52^{\prime} 43^{\prime \prime} \mathrm{N}$ & $6^{\circ} 17^{\prime} 36^{\prime \prime} \mathrm{W}$ & 12 & 19.0 & $16.5-21.7$ & 276 \\
HOUCEIMA & HCM & $35^{\circ} 14^{\prime} 57^{\prime \prime} \mathrm{N}$ & $3^{\circ} 55^{\prime} 58^{\prime \prime} \mathrm{W}$ & 80 & 17.9 & $15.0-20.7$ & 195 \\
FES & FES & $3^{\circ} 01^{\prime} 59^{\prime \prime} \mathrm{N}$ & $5^{\circ} 00^{\prime} 01^{\prime \prime} \mathrm{W}$ & 406 & 16.6 & $12.0-21.1$ & 320 \\
\hline
\end{tabular}

Mean values of five growing seasons (2011/12-2015/16), source:www.historique-meteo.net

\section{Genetic Diversity Analysis}

Biochemical markers were used to assess the intra-polymorphism of studied lentil landraces (LR) through comparing the poly-peptide chains protein patterns from five samples per landrace. The assessment of genetic diversity was based on sodium dodecyl sulfate polyacrylamide gel electrophoresis (SDS-PAGE) as described by Laemmli(1970). Total proteins were extracted using buffer of $0.3 \mathrm{M}$ Tris/ $\mathrm{HCl}(\mathrm{pH} 6.8), 1 \%$ SDS, 0.3\% of 2-mercapto-ethanol and 8\% glycerol (weight/volume ratio of 1:20). Seed protein extracts were analyzed by a vertical slab gel in a discontinuous buffer system and to which $10 \mu \mathrm{l}$ protein extract solution was loaded in $14 \%$ polyacrylamide gel. Molecular weights of the dissociated polypeptides were calculated using molecular weight protein marker (8KDa-220KDa). Protein bands were scored 1 as present band or 0 as absent band in the electrophoretic profile.

\section{Determination of Nutritional Parameters}

The nutritional value of eight landraces and four improved varieties was determined. Quantitative chemical analyses were conducted to estimate seeds content of crude proteins (Kjeldhal method), total carbohydrates (spectrometer at 340), and neutral fibers (Van Soest and Wine method). Lipids were extracted with Heptane using Soxhlet and the content was determined using gas chromatography Mass Spectrometry. Fatty acid profiles of studied lentils were determined using gas chromatograph method.

Concerning essential minerals (iron $(\mathrm{Fe})$, magnesium $(\mathrm{Mg})$, zinc $(\mathrm{Zn})$, calcium $(\mathrm{Ca})$, phosphorus $(\mathrm{P})$, potassium $(\mathrm{K})$, manganese $(\mathrm{Mn})$ ), seeds, seed coat and cotyledons samples have been wet digested in a mixture of nitric and perchloric acids and the concentration of each one was determined using atomic absorption spectrophotometry. While, thecontent of anti-oxidant components as total phenols and condensed tannins was determined according respectively to Folin-Ciocalteuand Julkumen Titto methods.

\section{DATA ANALYSIS}

Genetic diversity and genetic differentiation of landraces were assessed using Gen Alex 6.1 (Peakall and Smouse, 2006). Genetic diversity was estimated through the percentage of polymorphic loci (P), expected heterozygosity (He), 
number of different alleles (Na) per loci, number of effective alleles $(\mathrm{Ne})$ per loci and Shannon-Weaver's genetic diversity Index (SWI) (Shannon and Weaver, 1949). Genetic differentiation parameter (PhiPT) was used to measure the similarity of pairwise genotypes from the entire collection. Phi'PT represents the proportion of PhiPT relative to the maximum variability proportion attainable PhiPTmax calculated as $\frac{\text { PhiPT }}{\text { PhiPTmax }}$. The assessment of genetic diversity for each population independently of the sample size was measured as derived diversity of total molecular variation by dividing the sum of squares within population value (SSWP) by the number of individuals reduced by one (n-1): $\frac{\text { SSWP }}{\mathrm{n}-1}$. Seed exchange between pairwise landraces of geographic site $(\mathrm{Nm})$ was estimated as the average of seed migrants over generations from one to the other population in a spatial level, using genetic differentiation parameter (PhiPT) and was calculated on the base of the following formula: $\left.\mathrm{Nm}=0.25\left[\left(\frac{1}{\mathrm{PhiPT}}\right)-1\right)\right]$. Seed exchange value $(\mathrm{Nm})$ is considered high when $\mathrm{Nm} \geq$ 1.000; intermediate $(0.250-0.990)$, and low $(0.000-0.249)$. The relationship among landraces was carried out using Nei genetic distance (NeiGD) calculated between pairwise landraces as the proportion of the variance among populations relative to the total variance (Nei, 1973).

\section{RESULTS AND DISCUSSIONS}

\section{Genetic Diversity}

A total of 40 reproductive scored bands were identified in the high-protein variation area of the electrophoretic profile (10-97kDa) where the main storage proteins in lentil seeds as 7S globulins (45-50 kDa) and $11 \mathrm{~S}$ globulins (around $20 \mathrm{kDa}$ in a basic subunit and $40 \mathrm{kDa}$ in an acid subunit) migrate (Scippa et al, 2010; Zaccardelli et al, 2011) (Figure 1). The number of scored bands was higher than those scored in lentil varieties of Bangladesh (23 polypeptide bands) (Madina et al, 2013) and of India (21 polypeptide bands) (Prafull et al, 2018) studies. Whereas, it was lower than those recorded in lentil germplasm of Pakistan (55 protein bands) (Sultana et al, 2006). Genetic diversity parameters for each population are listed in table 2. The average of polymorphism was 30.6\% ranging from $17.5 \%$ to $80 \%$ (Table 2). Compared to lentil Mediterranean cores, the funding polymorphism level was similar to those found in lentil germoplasm from Spain (29.6\%) (Cristóbal\& Herrero, 2016) and is little raised than those from Syria and Egypt (28\%) (El Nahas et al, 2011), and in lentil landraces from Cyprus (28\%) (Piergiovanniand Taranto, 2003). However, it is higher than those of Tunisia (17.4\%), Algeria (16.9\%) and Greece (16.1\%) and lower than that found in Italian landraces (34\%) according to Piergiovanni and Taranto (2003) study.

Genetic parameters underline the allelic richness of studied landraces in spite of the small samples size compared to the origin area. The average of alleles number per locus of all landraces (1.191) is in accordance with that obtained of Turkish (1.181), Greek (1.191) and Chilean lentil landraces (1.201) (Erskine and Muehlbauer, 1991) and lower than the average of alleles number per locus found in Spanish populations (1.351) (Cristóbaland Herrero, 2016). However, the range variation of alleles richness per locus among Moroccan's landraces varied from 1.010 for RHM to 1.775 for ZAER that is similar with that obtained among Spanish landraces (1.058-1.529) (Erskine, 1997) and those among landraces from different geographic origins (1.143-1.714) (Ferguson et al, 1998). While, effective number of alleles and Shannon's genetic diversity Index values ranged respectively from 1.064 to 1.615 and from 0.072 to 0.482 . These results evidenced the genetic richness of Moroccan's landraces particularly in ZAER landrace (Table 2). Genetic variability assessed among these local cores might be behind dynamic adaptation ability of these landraces to their specific environmental constraints. Indeed, the landrace might represent a useful source of genes candidates associated to climate stresses. 


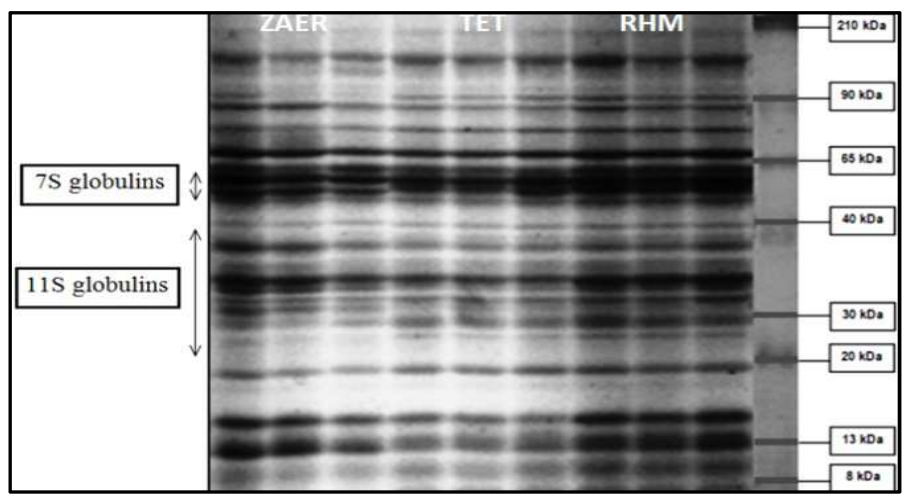

Figure 1: Example of Moroccan's Lentil Landraces (ZAER, TET, and RHM) Seed Storage Protein Banding Pattern Obtained by SDS-PAGE Electrophoresis

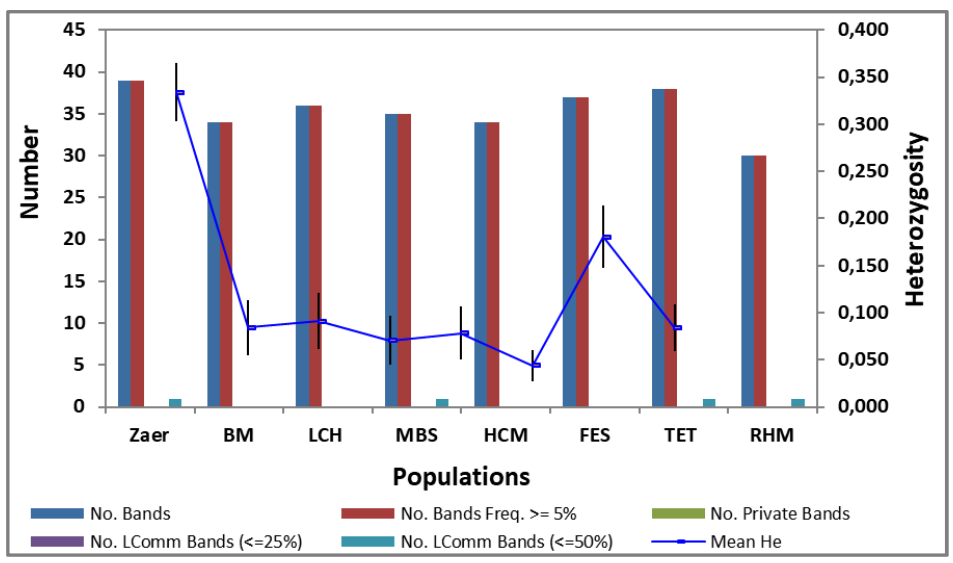

Figure 2: Band Patterns across the Main Lentil Landraces Cropped in Morocco

Table 2: Genetic Diversity Parameters for the Most Cropped Landraces of Lentil in Morocco

\begin{tabular}{|l|cccccc|}
\hline Landrace & Na & Ne & SWI & He & UHe & P \\
\hline Zaer & $1.775 \pm 0.076$ & $1.615 \pm 0.063$ & $0.482 \pm 0.043$ & $0.334 \pm 0.031$ & $0.371 \pm 0.035$ & 80.0 \\
TET & $1.450 \pm 0.094$ & $1.317 \pm 0.063$ & $0.269 \pm 0.046$ & $0.181 \pm 0.033$ & $0.201 \pm 0.036$ & 50.0 \\
RHM & $1.010 \pm 0.093$ & $1.136 \pm 0.043$ & $0.128 \pm 0.037$ & $0.084 \pm 0.025$ & $0.093 \pm 0.028$ & 25.0 \\
LCH & $1.100 \pm 0.086$ & $1.177 \pm 0.059$ & $0.129 \pm 0.042$ & $0.091 \pm 0.030$ & $0.101 \pm 0.033$ & 20.0 \\
BM & $1.025 \pm 0.091$ & $1.163 \pm 0.057$ & $0.118 \pm 0.041$ & $0.084 \pm 0.029$ & $0.094 \pm 0.033$ & 17.5 \\
MBS & $1.050 \pm 0.087$ & $1.131 \pm 0.051$ & $0.102 \pm 0.037$ & $0.071 \pm 0.026$ & $0.078 \pm 0.029$ & 17.5 \\
HCM & $1.025 \pm 0.091$ & $1.150 \pm 0.055$ & $0.111 \pm 0.039$ & $0.0778 \pm 0.028$ & $0.087 \pm 0.031$ & 17.5 \\
FES & $1.100 \pm 0.078$ & $1.064 \pm 0.027$ & $0.072 \pm 0.026$ & $0.044 \pm 0.017$ & $0.049 \pm 0.019$ & $\mathbf{1 7 . 5}$ \\
\hline \multicolumn{1}{|c|}{ Mean } & $\mathbf{1 . 1 9 1} \pm \mathbf{0 . 0 3 5}$ & $\mathbf{1 . 2 1 9} \pm \mathbf{0 . 0 2 1}$ & $\mathbf{0 . 1 7 6} \pm \mathbf{0 . 0 1 6}$ & $\mathbf{0 . 1 2 1} \pm \mathbf{0 . 0 1 1}$ & $\mathbf{0 . 1 3 4} \pm \mathbf{0 . 0 1 2}$ & $\mathbf{3 0 . 6} \pm \mathbf{8 . 1}$ \\
\hline
\end{tabular}

$\mathbf{N a}:$ Number of different alleles per loci, Ne : Number of effective alleles per loci $\left(1 /\left(\mathrm{p}^{2}+\mathrm{q}^{2}\right)\right.$, SWI: ShannonWeaver's genetic diversity Index $(-1 \times(p \operatorname{Ln}(p)+q \operatorname{Ln}(q))$, He : Expected Heterozygosity (2pq), UHE : Unbiased Expected Heterozygosity ( $2 \mathrm{~N} x \mathrm{He} /(2 \mathrm{~N}-1))$ where for Diploid binary data and assuming Hardy-Weinberg Equilibrium (p $=1-\mathrm{q}), \mathbf{P}:$ percentage of Polymorphic loci,

Otherwise, molecular variance analysis revealed that most variance was attributed among landraces (57\%) than within landraces (43\%). This result suggested a substantial genetic differentiation between pairwise landraces based on PhiPT values (PhiPT $=0,569^{* * *}$ ) with different degree since PhiPT has varied from $0.176^{*}$ to $0.783^{* * *}$ (Table 4 ). The highest genetic differentiation (PhiPT) has been recorded among samples within all pairwise of RHM-BM $\left(0.783^{* * *}\right)$, RHM-FES 
$\left(0.780^{* * *}\right)$, RHM-LCH $\left(0.753^{* * *}\right)$, RHM-HCM $\left(0.747^{* * *}\right)$ and MBS-FES $\left(0.746^{* *}\right)$. The high genetic differentiation of RHM suggested not sufficient seed exchange between farmers of RHM region and BM, FES, LCH and HCM sites. This result is approved by Nei's genetic distance (0.580-0.651) and supported by low estimated values of seed exchange Nm (0.07-0.09) promoting therefore a genetic distinction of RHM (Table 3). Contrary, a low genetic differentiation revealed between Zaer landrace and all of BM, HCM, TET, MBS, LCH, FES and RHM was promoted by a significant seeds exchange $(0.34<\mathrm{Nm}<0.80)$. Zaer landrace was promoted with geographical label linked to distinctive seed quality (Geographical Indication label IG) (Benbrahim et al., 2017). Thus, seeds exchange through farmer's involvement between lentil landraces of geographical areas might be induced by traits of interest such as climate change resilience, consumers' sought phenotypic traits and organoleptic quality or by geographical proximity promotion as between FES-TET (1.17) (Table 5).

Otherwise, genetic differentiation among landraces could be attributed to both natural and human selection impact on the assessed loci. The derived diversity $\left(\frac{S S W P}{n-1}\right)$ varied from 1.5 for both HCM and MBS to 7.6 for ZAER with an average of 2.85 (Table 3). The extent of gene differentiation (Phi'PT=0.664) relative to the total population variability $\left(\mathrm{PhiPT}=0,569^{* * *}\right)$ and relative to the maximum of attainable variability proportion $(\mathrm{PhiPTmax}=0,858)$ was independent to the within population diversity rate (Table 4). Phi'PT varied from 0.208 (FES-TET) to 0.880 (RHM-BM) was supported by genetic distance respectively 0.134 and 0.651 (Table 5). These results may provide useful information on relative gene differentiation between pairwise landraces of the main lentil cropped geographic areas.

Table 3: Derived Genetic Diversity within Studied Lentil Landraces

\begin{tabular}{|l|c|c|c|c|c|c|c|c|c|}
\hline & Zaer & BM & LCH & MBS & HCM & FES & TET & RHM & Mean \\
\hline $\mathbf{n}$ & 5 & 5 & 5 & 5 & 5 & 5 & 5 & 5 & 5 \\
\hline SSWP & 30.4 & 6.8 & 6.4 & 6.0 & 6.0 & 6.4 & 18.4 & 10.8 & 11.4 \\
\hline SSWP/(n-1) & 7.6 & 1.7 & 1.6 & 1.5 & 1.5 & 1.6 & 4.6 & 2.7 & 2.85 \\
\hline
\end{tabular}

SSWP: Sum of Squares within Population; n: number of simples

Table 4: Statistic Parameters of Genetic Diversification of Lentil Moroccan Landraces

\begin{tabular}{|l|c|c|c|c|c|c|c|}
\hline SDS-PGE & df & SS & MS & Est. Var. & $\%$ & Value & P ( $\boldsymbol{\alpha} \leq 0.05)$ \\
\hline PhiPT & 7 & 151,650 & 21,664 & 3,763 & $\mathbf{5 7 \%}$ & $\mathbf{0 , 5 6 9}$ & $0,001^{* * *}$ \\
& 32 & 91,200 & 2,850 & 2,850 & $\mathbf{4 3 \%}$ & & \\
PhiPT max & 39 & 242,850 & & 6,613 & $100 \%$ & $\mathbf{0 , 8 5 8}$ & $0,001^{* * * *}$ \\
Phi'PT & & & & & & $\mathbf{0 , 6 6 4}$ & $0,001^{* * *}$ \\
\hline
\end{tabular}

Df degree of freedom, SS sum square, MS mean square, Est. Var estimated variability,

PhiPT is based on standard permutation across the full data set 
Table 5: Genetic Differentiation Parameters and Nei Genetic Distance (NGD) Among Pair wise Landraces of Lentil

\begin{tabular}{|c|c|c|c|}
\hline Pairwise population & PhiPT & Phi'PT & NeiGD \\
\hline Zaer-MBS & $0,306^{*}$ & 0,397 & 0,345 \\
\hline Zaer-LCH & $0,407^{*}$ & 0,529 & 0,433 \\
\hline Zaer-BM & $0,238^{* *}$ & 0,310 & 0,252 \\
\hline Zaer-TET & $0,302^{*}$ & 0,435 & 0,386 \\
\hline Zaer- RHM & $0,421^{* *}$ & 0,567 & 0,369 \\
\hline Zaer-HCM & $0,242^{* *}$ & 0,313 & 0,271 \\
\hline Zaer- FES & $0,412^{\cdots *}$ & 0,535 & 0,476 \\
\hline BM-MBS & $0,707^{* *}$ & 0,768 & 0,296 \\
\hline BM-LCH & $0,652^{* *}$ & 0,711 & 0,245 \\
\hline BM-TET & $0,598^{* *}$ & 0,710 & 0,460 \\
\hline BM- RHM & $0,783^{* *}$ & 0,880 & 0,651 \\
\hline BM- HCM & $0,673^{* *}$ & 0,732 & 0,218 \\
\hline BM-FES & $0,699^{* *}$ & 0,762 & 0,310 \\
\hline LCH-MBS & $0,503^{*}$ & 0,545 & 0,099 \\
\hline LCH-TET & $0,563^{*}$ & 0,667 & 0,383 \\
\hline LCH- RHM & $0,753^{*}$ & 0,844 & 0,501 \\
\hline LCH- HCM & $0,657^{* *}$ & 0,712 & 0,187 \\
\hline LCH- FES & $0,713^{* *}$ & 0,775 & 0,301 \\
\hline MBS- TET & $0,582^{* *}$ & 0,687 & 0,404 \\
\hline MBS- RHM & $0,741^{* *}$ & 0,828 & 0,538 \\
\hline MBS- HCM & $0,364^{* *}$ & 0,394 & 0,094 \\
\hline MBS- FES & $0,746^{*}$ & 0,809 & 0,334 \\
\hline HCM- TET & $0,531^{*}$ & 0,626 & 0,361 \\
\hline HCM- RHM & $0,747^{* *}$ & 0,835 & 0,535 \\
\hline HCM- FES & $0,698^{* *}$ & 0,757 & 0,295 \\
\hline FES-TET & $0,176^{*}$ & 0,208 & 0,134 \\
\hline FES-RHM & $0.780^{\circ}$ & 0,874 & 0.698 \\
\hline TET- RHM & $0.563^{*}$ & 0,689 & 0.416 \\
\hline
\end{tabular}

Significant at $0.05(*), 0.01(* *)$ and at $0.001(* * *)$ probability level respectively

\section{Nutritional Value}

The nutrient components content of lentil seeds varied widely among landraces and between landraces and improved varieties as showed in tables $6 \mathrm{a}, 6 \mathrm{~b}, 7$, and 8 and in figure 3. Our results showed a large range of macronutrients content variability among Moroccans' lentil landraces in regards to crude proteins (26.8 - 33.8\%), total carbohydrate (46.4$58.3 \%)$, neutral fibers $(39.7-46.4 \%)$ and fat content $(1.13-2.10 \mathrm{mg} / 100 \mathrm{~g}$ ) (Table 6a). This variation attests genetic variability that might be affected by environmental factors. The large range variability of proteins content was in accordance with the finding in landraces of Turkey (22.7-31.9 g/100g) according to (Karaköy et al,2012) result. The mean proteins value (30.3\%) in lentil seeds of Moroccans' landraces is higher than this of Turkey (25.6\%) and similar to this of Pakistan (29.8\%)(Zia-UL-Haq et al, (2011); Karaköy et al, (2012)). Furthermore, lentil seeds are healthy source of neutral dietary fibers (44\%) of which only about 3\% are indigestible (Lignin) in accordance with Bednar et al, (2001) study. The range variation observed for total carbohydrate and lipids content are in agreement with those reported by Zia-UL-Haq et al, (2011)for lentil landraces of Pakistan respectively 54.1\% - 55.8\% and $1.93-2.15 \%$. The low content of lipids revealed 
in lentil seeds (about $1.2 \mathrm{mg} / 100 \mathrm{~g}$ ) are mainly composed of unsaturated fatty acids (USFA) (83.9\%)(Table 7). The finding amounts of total lipids and fatty acids profile are in accordance with the values reported by Ryan et al, (2007). A total of seven fatty acids were identified based on the number of carbons of where five are mostly abundant in lentil. Palmitic acid (16:0) and stearic acid (18:0) are the most abundant saturated fatty acid (SFA) regarding their parts of total fatty acid (16.1\%) respectively $14.6 \%$ and $1.33 \%$. While, linoleic acid (18:2 n-6), oleic acid (18:1n-9) and $\alpha$-linoleic acid (18:3 n-3) are the most abundant unsaturated fatty acid (USFA) according to their contribution to total fatty acid (83.9\%) respectively 48.6\%, 23.2\% and 11.9\%. Linoleic acid was the main component of total lipids extracted from studied lentil seeds samples. The ratio of USFA/SFA is about 5.2 revealing the healthy source of Moroccan lentils lipids. Indeed, essential USFA as linoleic ( $\omega-3 \& \omega-6)$, oleic $(\omega-3)$ and $\alpha$-linoleic $(\omega-3, \omega-6 \& \omega-9)$ acids provide health improvement and disease-prevention particularly of cardiovascular diseases, diabetes type 2 and are involved in balancing total cholesterol (Simopoulos, 2008; Simopoulos, 2010).

Table 6a: Macronutrients Content of Lentil Landraces

\begin{tabular}{|c|c|c|c|c|c|c|c|c|c|c|c|}
\hline LR & \begin{tabular}{|c|} 
Seed \\
coat $(\%)$
\end{tabular} & \begin{tabular}{|c} 
Moisture \\
$(\%)$
\end{tabular} & $\begin{array}{c}\text { Ash rate } \\
(\%)\end{array}$ & $\begin{array}{c}\text { Crude } \\
\text { Proteins }\end{array}$ & Carbohydrate & Lipids & $\begin{array}{c}\text { Neutral } \\
\text { Fiber }\end{array}$ & Lignin & Tannin & $\begin{array}{l}\text { Tannin in } \\
\text { seed coat }\end{array}$ & Polyphenols \\
\hline LCH & $11.1^{\mathrm{a}}$ & $10.2^{\mathrm{ab}}$ & $2.27^{b}$ & $29.2^{c}$ & $51.2^{\mathrm{c}}$ & $1.19^{\mathrm{abc}}$ & $46.7^{\mathrm{a}}$ & $1.44^{\mathrm{bc}}$ & $4.94^{\mathrm{de}}$ & $2.20^{\mathrm{b}}$ & $8.80^{\mathrm{a}}$ \\
\hline RHM & $12.0^{\mathrm{a}}$ & $10.4^{\mathrm{ab}}$ & $2.51^{\mathrm{a}}$ & $29.2^{c}$ & $53.7^{\mathrm{b}}$ & $1.20^{\mathrm{abc}}$ & $43.5^{\mathrm{d}}$ & $1.54^{\mathrm{b}}$ & $8.19^{\mathrm{a}}$ & $3.06^{\mathrm{a}}$ & $7.65^{\mathrm{bc}}$ \\
\hline TET & $11.7^{\mathrm{a}}$ & $107^{\mathrm{a}}$ & $2.11^{\mathrm{b}}$ & $33.0^{\mathrm{a}}$ & $53.7^{\mathrm{b}}$ & $1.22^{\mathrm{ab}}$ & $44.9^{\mathrm{bc}}$ & $1.31^{\mathrm{bc}}$ & $5.45^{\mathrm{d}}$ & $1.76^{\mathrm{c}}$ & $7.41^{\mathrm{bc}}$ \\
\hline MBS & $10.7^{\mathrm{a}}$ & $10.5^{\mathrm{ab}}$ & $2.25^{\mathrm{b}}$ & $30.3^{\mathrm{b}}$ & $54.0^{\mathrm{b}}$ & $1.15^{\mathrm{c}}$ & $46.0^{\mathrm{a}}$ & $1.31^{\mathrm{bc}}$ & $4.53^{\mathrm{e}}$ & $1.15^{\mathrm{d}}$ & $7.82^{b}$ \\
\hline FES & $11.3^{\mathrm{a}}$ & $10.4^{\mathrm{ab}}$ & $2.23^{\mathrm{b}}$ & $27.7^{\mathrm{d}}$ & $47.0^{\mathrm{d}}$ & $1.18^{\mathrm{bc}}$ & $45.6^{\mathrm{ab}}$ & $1.29^{\mathrm{bc}}$ & $6.99^{\mathrm{b}}$ & $1.57^{\mathrm{c}}$ & $8.62^{\mathrm{a}}$ \\
\hline HCM & $11.5^{\mathrm{a}}$ & $10.4^{\mathrm{ab}}$ & $2.57^{\mathrm{a}}$ & $30.5^{b}$ & $52.5^{\mathrm{bc}}$ & $1.16^{\mathrm{c}}$ & $41.7^{\mathrm{e}}$ & $2.01^{\mathrm{a}}$ & $6.04^{\mathrm{c}}$ & $2.03^{b}$ & $6.42^{\mathrm{d}}$ \\
\hline BM & $11.1^{\mathrm{a}}$ & $10.1^{\mathrm{b}}$ & $2.51^{\mathrm{a}}$ & $30.3^{\mathrm{b}}$ & $53.4^{\text {bc }}$ & $1.16^{\mathrm{c}}$ & $33.9^{\mathrm{f}}$ & $1.25^{\mathrm{c}}$ & $7.71^{\mathrm{a}}$ & $3.07^{\mathrm{a}}$ & $7.22^{\mathrm{c}}$ \\
\hline ZAER & $11.6^{\mathrm{a}}$ & $10.5^{\mathrm{ab}}$ & $2.14^{\mathrm{b}}$ & $32.6^{\mathrm{a}}$ & $56.8^{\mathrm{a}}$ & $1.24^{\mathrm{a}}$ & $44.7^{\mathrm{c}}$ & $1.36^{\mathrm{bc}}$ & $4.44^{\mathrm{e}}$ & $1.54^{\mathrm{c}}$ & $7.64^{\mathrm{bc}}$ \\
\hline MEAN & $11.4 \pm 0.43$ & $10.4 \pm 0.06$ & $2.32 \pm 0.04$ & $30.3 \pm 0.36$ & $52.8 \pm 0.59$ & $1.19 \pm 0.008$ & $44.0 \pm 0.43$ & $1.44 \pm 0.05$ & $6.04 \pm 0.47$ & $2.02 \pm 0.24$ & $7.70 \pm 0.15$ \\
\hline Range & $8.33-14.8$ & 10.1-10.9 & $2.04-2.80$ & $26.8-33.8$ & $46.4-58.3$ & $1.11-1.26$ & $39.7-46.4$ & $1.13-2.10$ & $3.62-9.56$ & $0.95-3.38$ & $5.67-8.83$ \\
\hline CV\% & 18.3 & 2.67 & 9.14 & 5.76 & 5.49 & 3.15 & 4.74 & 18.6 & 35.0 & 33.4 & 9.81 \\
\hline$\underset{(\alpha=0.05)}{\operatorname{LSD}}$ & 4.05 & 0.47 & 0.17 & 0.99 & 2.21 & 0.05 & 0.69 & 0.27 & 0.09 & 0.01 & 0.46 \\
\hline
\end{tabular}

Proteins, Carbohydrates and fibers are expressed in g/100g; Lipids, Tannin and Polyphenols are expressed in $\mathrm{mg} / \mathrm{g}$

Table 6b: Mean, Range and Coefficient of Variation (CV) for Macronutrients Content of Cropped Lentil in Morocco

\begin{tabular}{|c|c|c|c|c|c|c|c|c|}
\hline \multirow{2}{*}{ Macronutrients } & \multicolumn{3}{|c|}{ Landraces } & \multicolumn{3}{|c|}{ Varieties } & \multirow{2}{*}{ LSD } & \multirow{2}{*}{ F-value } \\
\hline & $\operatorname{Mean} \pm$ SE & Range & CV (\%) & Mean \pm SE & Range & CV (\%) & & \\
\hline 1000 -seeds weight & $34.0^{\mathrm{a}} \pm 0.8$ & $28.5-42.9$ & 11.2 & $32.1^{\mathrm{b}} \pm 0.7$ & $28.7-35.3$ & 7.7 & 0.53 & $56.2^{* * *}$ \\
\hline Proteins & $30.3^{\mathrm{a}} \pm 0.4$ & $26.8-33.8$ & 5.8 & $28.6^{\mathrm{b}} \pm 0.2$ & 27.3-29.9 & 2.8 & 0.43 & $68.1^{* * *}$ \\
\hline Carbohydrates & $52.8^{\mathrm{a}} \pm 0.6$ & $46.4-58.3$ & 5.5 & $49.8^{\mathrm{b}} \pm 0.3$ & $48.9-52.2$ & 2.4 & 0.76 & $64.0^{* * *}$ \\
\hline Lipids & $1.19 \mathrm{a} \pm 0.01$ & $1.11-1.26$ & 3.1 & $1.19^{\mathrm{a}} \pm 0.01$ & $1.13-1.26$ & 3.5 & 0.03 & $0.41^{\mathrm{NS}}$ \\
\hline Neutral fiber & $44.0^{\mathrm{b}} \pm 0.4$ & $39.7-46.4$ & 4.7 & $44.5^{\mathrm{a}} \pm 0.5$ & $41.2-46.3$ & 4.0 & 0.29 & $11.9^{* *}$ \\
\hline Lignin & $1.44^{\mathrm{a} \pm 0.05}$ & $1.13-2.10$ & 18.6 & $1.47^{\mathrm{a} \pm 0.08}$ & $1.11-1.92$ & 17.9 & 0.13 & $0.25^{\mathrm{NS}}$ \\
\hline Condensed tannins & $6.04^{b} \pm 1.24$ & $3.62-9.56$ & 26.1 & $7.43^{\mathrm{a}} \pm 1.47$ & $4.60-9.95$ & 27.3 & 0.09 & $3.26^{*}$ \\
\hline Polyphenols & $7.70^{\mathrm{a}} \pm 0.15$ & $5.67-8.83$ & 9.8 & $7.41^{\mathrm{b}} \pm 0.23$ & $6.03-8.24$ & 11.0 & 0.17 & $12.8^{* *}$ \\
\hline
\end{tabular}

Proteins, Carbohydrates and fibers are expressed in g/100g; Lipids, Tannin and Polyphenols are expressed in $\mathrm{mg} / \mathrm{g}$ 
Table 7: Total Lipids and Fatty Acid Composition of Lentil Landraces

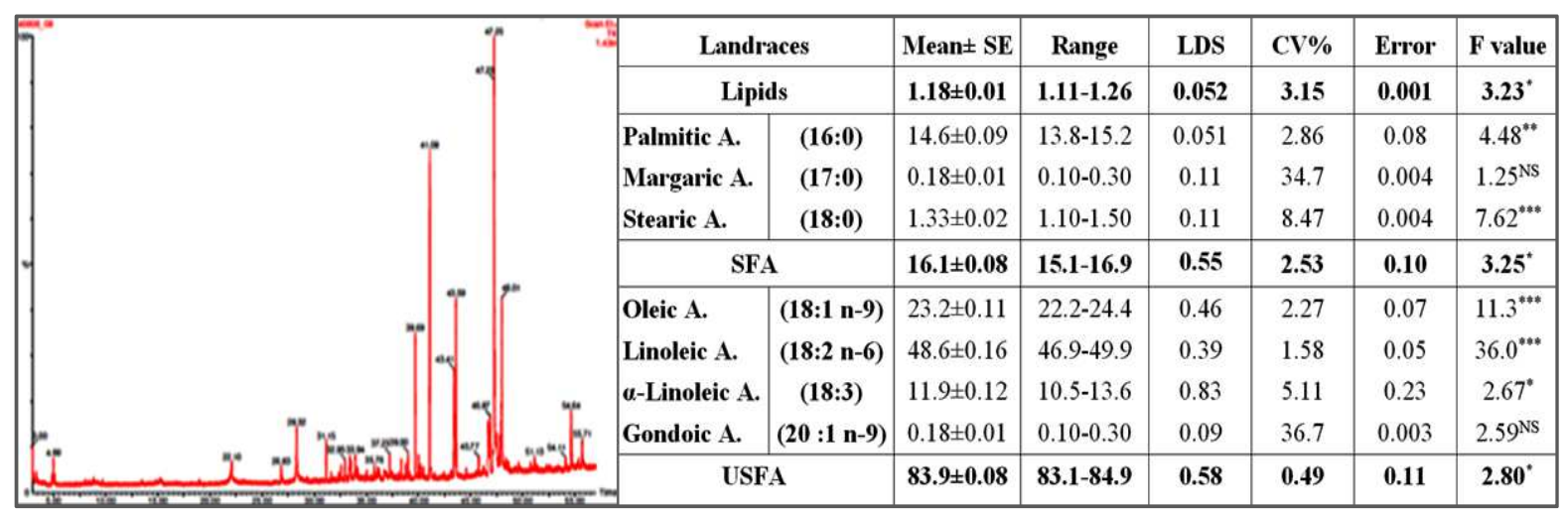

The mean content of total phenols (TP) in studied lentil seeds (7.60 mg Gallic acid equivalent (GAE)/100g) was higher and varied significantly among landraces (6.67-8.83) compared to that among improved varieties (6.03-8.24) (Table 6b). This result highlights the health-promoting properties of Morocco lentil landraces related to the rich amount of total phenol compounds in agreement with Kumar et al, (2017). According to Faller and Fialho, (2009)study, polyphenols amount in lentil seeds depends on genetic factor, soil composition, growing and post-harvest conditions. Many previous studies under lined their antioxidant activity providing protective mechanisms against free radicals (Amarowics et al, (2009); Oomah et al, 2011). Previous studies attested that the bioactive compounds of lentil seeds reduce the incidence of diabetes, obesity, cancers and cardiovascular diseases(Aslani et al, (2015);Kumar et al, (2017). The major compounds of total phenols are the condensed tannins (PA) which are a group of naturally occurring polyphenolic bioflavonoids(Oomah et al, 2011). Despite their agronomic advantages in the defense against pests and their potential health-benefiting properties, tannins have an anti-nutritional effect reducing the bioavailability of nutrients (Kumari and Jain, 2012). The mean content of condensed tannins $(6.04 \mathrm{mg} / \mathrm{g} \mathrm{DM})$ is mainly concentrated in seed coat (67\%). Indeed, a positive and significant correlation $\left(\mathrm{r}=0.618^{* * *}\right)$ was revealed between seed coat part and condensed tannins. Fortunately, seed coat represents a small part of the seed weight (11.4\%) ranging from 8.3 to $14.8 \%$ and both soaking and dehulling might reduce the tannin content(Khandelwala et al, 2010)(Table 6a). Otherwise, seeds coat might represent a potential source of health benefits considering their dietary fiber richness.

In current study, the ash content of lentils seeds ranged from 2.04 to $2.84 \mathrm{mg} / 100 \mathrm{~g}$ in agreement with the finding (2.48 to $2.84 \mathrm{mg} / 100 \mathrm{~g}$ ) of Wang et al., (2009). The mean concentration of major micronutrients in lentil seeds for studied landraces was $7.66 \mathrm{mg} / 100 \mathrm{~g}$ for iron, $445 \mathrm{mg} / 100 \mathrm{~g}$ for phosphorus, $116.9 \mathrm{mg} / 100 \mathrm{~g}$ for magnesium, $48.8 \mathrm{mg} / 100 \mathrm{~g}$ for calcium and $944.5 \mathrm{mg} / 100 \mathrm{~g}$ for potassium (Table 8). Compared to the level of improved varieties, landraces showed larger range variability and higher mean value of most of dietary essential minerals content (Figure 3 ). In our study, the range variation among landraces ranged from 6.57 to 8.26 for iron, from 102.0 to 126.8 for magnesium, from 3.74 to 4.83 for zinc, from 44.8 to 55.8 for calcium, from 431.4 to 454.1 for phosphorus, from 922.0 to 956.5 for potassium and from 1.27 to 1.37 for manganese (Figure 3). The great range diversity in micronutrients concentration observed within Moroccan lentil landraces is in accordance with that reported by Karaköy et al (2012) in 39 lentil landraces of turkey. The concentration level of minerals in lentil seeds seems depending firstly on genetic factors that might be affected by cropped environment as reported also by Crusak and Cakmak (2002). These results are similar to the finding for Turkey landraces for magnesium and manganese (Karaköy et al, 2012), and for lentil genotypes cropped in Saudi Arabia for iron (Alghamdi 
et al, 2014). Moroccan's landraces of lentil are more richness in phosphorus and potassium which might be a consequence of high input of phosphorus and potassium fertilizer during the set of lentil crop. While, zinc concentration was higher than the finding for lentil genotypes of Saudi Arabia and lower than that found for lentil landraces of Turkey. In contrary, the calcium concentration was lower than this found for both Turkey landraces and Saudi Arabia lentil genotypes (Karaköy et al, 2012; Alghamdi et al, 2014).

Iron and zinc are the two major worldwide human nutritional deficiencies problem that accounts for almost twothirds of the childhood death worldwide (Welch and Graham, 2004). Genetic approach is considerate to be the most economic enduring and cost effective strategy toward improving iron and zinc content than dietary fortification programs. Breeding efforts including the utilization of valuable genetic resources available within landraces might be an effective approach to overcome lacking minerals problem. Our finding revealed the availability of valuable variant genotypes with a great potential associated with high level of nutrients useful in pre-breeding program for increasing nutritional value. This could be a promising approach to manage nutrient deficiencies. High and wide range of iron concentration in lentil seeds of studied Moroccan's landraces revealed the genetic potential of these valuable resources to cover the human requirement primary for iron $(\mathrm{Fe})$ and zinc $(\mathrm{Zn})$.
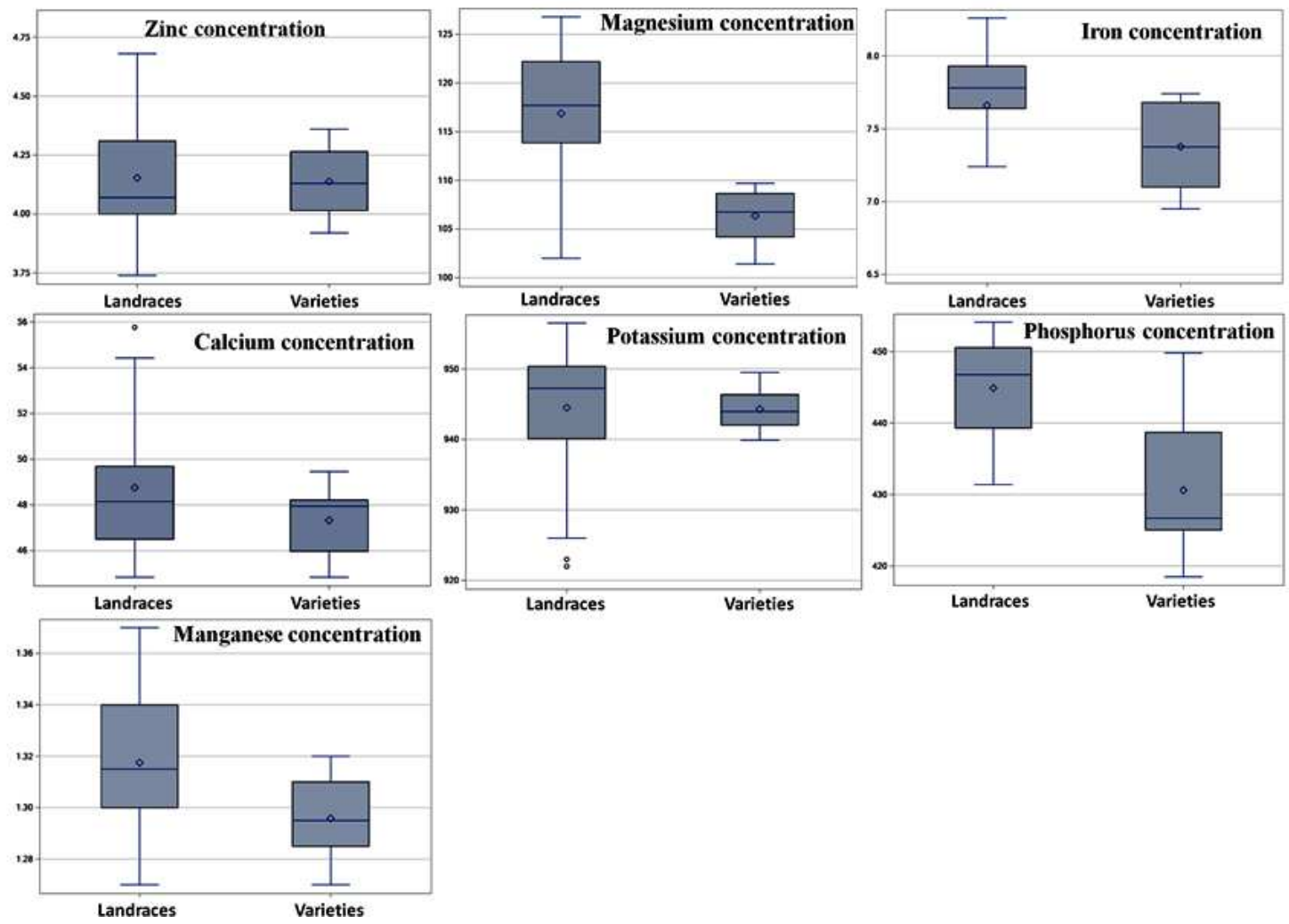

Figure 3: Major Micronutrient of Moroccan Cropped Lentil Expressed as mg/100g 
Table 8: Variance Factors of Minerals Components Among the Most Lentils Cultivars Cropped in Morocco

\begin{tabular}{|c|c|c|c|c|c|c|c|c|}
\hline $\begin{array}{l}\text { Source of } \\
\text { variation }\end{array}$ & DF & Iron & Mg & Zn & $\mathrm{Ca}$ & $\mathbf{P}$ & $\mathbf{K}$ & Mn \\
\hline Cultivars & 1 & 0.644 & 883.4 & 0.002 & 16.25 & 1631.2 & 0.307 & 0.004 \\
\hline Cult(gen.) & 10 & 0.407 & 89.5 & 0.139 & 16.78 & 208.8 & 208.6 & 0.001 \\
\hline Error & 22 & 0.071 & 10.4 & 0.02 & 1.27 & 0.45 & 2.04 & 0.0001 \\
\hline CV\% & & 5.68 & 6.80 & 5.53 & 5.24 & 2.41 & 0.83 & 1.86 \\
\hline LSD & & 0.195 & 2.37 & 0.104 & 0.83 & 2.25 & 1.05 & 0.01 \\
\hline F value & & $9.07^{* *}$ & $84.6^{* * *}$ & $0.09^{\mathrm{NS}}$ & $12.8^{* * *}$ & $172.5^{* * *}$ & $0.15^{\mathrm{NS}}$ & $27.6^{* * *}$ \\
\hline Mean LR & & $7.66^{\mathrm{a}}$ & $116.9^{a}$ & $4.15^{a}$ & $48.7^{a}$ & $444.9^{\mathrm{a}}$ & $944.5^{a}$ & $1.32^{\mathrm{a}}$ \\
\hline Mean Var. & & $7.38^{b}$ & $106.4^{b}$ & $4.14^{a}$ & $47.3^{b}$ & $430.6^{b}$ & $944.3^{a}$ & $1.29^{\mathrm{b}}$ \\
\hline Mean & & $7.57 \pm 0.07$ & $113.4 \pm 1.29$ & $4.15 \pm 0.04$ & $48.7 \pm 0.42$ & $440.1 \pm 1.77$ & $944.4 \pm 1.31$ & $1.31 \pm 0.004$ \\
\hline
\end{tabular}

\section{CONCLUSIONS}

The finding results revealed considerable genetic diversity according to biochemical markers and nutritional traits assessment. Current investigation revealed that lentil seeds could be a beneficial healthy source of essential macro and micro-nutrients of human requirements. The valuable diversity for the most common lacking minerals in human diet (Calcium, Phosphate, Iron, Zinc and Manganese contents) was recorded among lentil lines composing landraces. Hence, landraces might contain optional genetic resources of genotypes or allelic variants of candidate gene(s) useful in prebreeding for developing new varieties with nutritional beneficial traits. Further work is needed to identify promoted genotypes within Moroccan lentil landraces for their integration in breeding program to develop resilient varieties to climate stresses with an adding value of nutritional quality. This could be an effective genetic approach in long-term to improve consumer's nutritional status and reduce nutrients deficiencies adverse effects particularly in low-income rural households.

\section{REFERENCES}

1. Aguenaou H. (2007). La malnutrition invisible ou la faim cachée au Maroc et les stratégies de lutte. Biomatec Echo. 5(2): 158-164.

2. Alaoui L. (1991). Evaluation of the ironstatus of population of adults in Morocco: Influence of dietary intake. PhD thesis. State university of Oregon. Corvallis, OR, USA.

3. Alaoui L. (2005). Prévenir la carence en fer au Maroc. Bulletin Mensuel d'information et de liaison du PNTTA $n^{\circ} 131$. Ministère de l'Agriculture et de la Pêche Maritime /DERD.

4. Alghamdi, S. S.Khan, A. M. Ammar, M. H. El-Harty, E. H. Migdadi, H. M. and al. (2014). Phenological, nutritional and molecular diversity assessment among 35 introduced lentil (Lens culinarisMedik.) genotypes grown in Saudi Arabia. International Journal of Molecular Sciences. 15: 277-295.

5. Amarowicz, R. Estrella, I. Hernández, T. Dueñas, M. Troszynska, A. and Kosinska, A. (2009).Antioxidant activity of a red lentil extract and its fractions. International Journal of Molecular Sciences. 10: 5513-5527.

6. Arumuganathan, K. and Earle, ED. (1991). Nuclear DNA content of some important plant species. Plant Molecular Biology Reporter. 9: 208-218. 
7. Aslani, Z. Alipour, B. Mirmiran, P. Bahadoran, Z. (2015). Lentil's (Lens culinarisL.) functional properties in prevention and treatment of non-communicable chronic diseases: A review. International Journal of Nutrition and Food Sciences. 4(2-1): 1520.

8. Bednar, G.E.Patil, A.R. Murray, S.M.Grieshop, C.M.Merchen, N.R. Fahey, G.C.J.(2001). Starch and fiber fractions in selected food and feed ingredients affect their small intestinal digestibility and fermentability and their large bowel fermentability in vitro in a canine model. Journal of Nutrition. 131:276-286

9. Benbrahim, N. Es-saouabi, S. Es-safi, N. Gmouh, S. Gaboun, F. Mentag, R. (2016). Nutritional value of Moroccan's lentil and perspectives for sustainable uses. International conference on Pulses for Health, Nutrition and sustainable agriculture. Marrakech, Morocco. April 18-20, Poster.

10. Benbrahim, N. Taghouti, M. Zouahri, A. and Gaboun, F. (2017). On-farm conservation of Zaer lentil landrace in context of climate change and improved varieties competition. Universal Journal of Agricultural Research 5: 27-38p.

11. Cristóbal, MD. and Herrero, B. (2016). Genetic characterization of Spanish lentil landraces (Lens culinarisMedik.) by biochemical markers. Indian Journal of Agricultural Research. 50(3): 214-219.

12. EL Hioui, M., Ahami, A.O.T., Aboussaleh, Y. Rusinek, S. Dik, K. andSoualem, A. (2007), L'anémie nutritionnelle chez les enfants scolarisés dans une zone rurale et côtière du Nord-Ouest Marocain.Antropo. 15: 35-40.

13. El Menchawy, I. El Hamdouchi, A. El Kari, K.Saeid, N.Zahrou, FE.et al. (2015). Efficacy of Multiple Micronutrients Fortified Milk Consumption on Iron Nutritional Status in Moroccan Schoolchildren.Journal of Nutrition and Metabolism.

14. El Nahas, AI. El Shazly, HH. Ahmed, SM. and Omran, A. (2011).Molecular and biochemical markers in some lentil (Lens culinarisMedik.) genotypes.Annals of Agricultural Sciences. 56:105-112.

15. Erskine, W. and AdhamYand Holly, L. (1989).Geographic distribution of variation in quantitative traits in a world lentil collection.Euphytica 43: 97-103p.

16. Erskine, W. and Muehlbauer, FJ.(1991). Allozyme and morphological variability: outcrossing rate and core collection formation in lentil germplasm. Theoretical and Applied Genetics. 83: 119-125.

17. Erskine, W. (1997).Lessons for breeders from landraces of lentil.Euphytica 93: 107-112.

18. Esquinas-Alcazar, J.T. (1993). Plant genetic resources. In: M.D. Hayward, N.O. Bosemark and I. Romagosa (eds.). Plant Breeding: Principles and Prospects, Chapman \& Hall, London, UK. 33-51.

19. Faller, A. L. K., \&Fialho, E. (2009). The antioxidant capacity and polyphenol content of organic and conventional retail vegetables after domestic coking. Food Research International. 42: 210-215.

20. Faris, M. E. Takruri, H. R. and Issa, A. Y. (2013). Role of lentils (Lens culinaris L.) in human health and nutrition: a review. Mediterranean Journal of Nutrition and Metabolism. 6:3-16.

21. Fenchel, T. King, GM. Blackbum, TH.(2012). Symbiotic Systems.Bacterial Biogeochemistry (3 Edition) 9: 163-181.

22. Ferguson, ME. Robertson, LD. Ford-Lloyd, BV. Newbury, HJ. andMaxted, N. (1998). Contrasting genetic variation amongst lentil landraces from different geographic origins. Euphytica. 102: 265-273.

23. Grusam, M. A. and Cakmak, I. (2002).Plant nutritional Genomics.Chap. 12.Methods to improve the crop delivery of minerals to humans and livestock. 265-282. 
24. Gupta, D. S. Thavarajah, D. McGee, R. J. Coyne, C. J. Kumar, S. Thavarajah, P. (2016). Genetic diversity among cultivated and wild lentils for iron, zinc, copper, calcium and magnesium concentrations.Australian Journal of Crop Science. 10(10):1381-1387.

25. Hammer, K. and Laghetti, G. (2005).Genetic erosion - examples from Italy.Genetic Resources and Crop Evolution. 52: 629634.

26. Hammer, K. and Diederichsen, A. (2009). Evolution, Status and Perspectives for Landraces in Europe. In European landraces: on-farm conservation, management and use. Veteläinen M, Negri, V. and Maxted, N. (Eds).Bioversity International.Bioversity.Technical Bulletin. 15: 23-44.

27. Han, I.H.(2005).Oligosaccharide reduction, protein digestibility improvement, antioxidant activity determination and phenolic compounds identification in legumes.PhD Thesis, Washington State University.

28. Karaköy, T. Erdem, H. Baloch, S. F. Toklu, F. Eker, S. Kilian, B. and Özkan, H. (2012).Diversity of macro- and micronutrients in the Seeds of Lentil Landraces. Scientific World Journal. 9p.

29. Khandelwala, S. Udipib, S. A. Ghugreb, P. (2010). Polyphenols and tannins in Indian pulses: Effect of soaking, germination and pressure cooking. Food Research International. 43: 526-530.

30. Kumar, J. Gupta, D. S. Kumar, S. Gupta, S. and Singh, N. P. (2016). Current Knowledge on Genetic Bio-fortification in Lentil.Journal of Agricultural and Food Chemistry. 64 (33): 6383-6396.

31. Kumar, G. and Xu,B. (2017). Polyphenol-Rich Lentils and Their Health Promoting Effects. International Journal of Molecular Sciences. 18-2390. $26 p$

32. Kumari, M. and Jain, S. (2012). Tannins: an anti-nutrient with positive effect to manage diabetes. Research Journal of Recent Sciences. 1(12): 1-8.

33. Ladizinsky, G. (1979). The origin of lentil and wild gene pool.Euphytica 28: 179-187.

34. Laemmli, UK. (1970). Cleavage of structural proteins during the assembly of the head of bacteriophage T4.Nature.227: 680685.

35. Amrata, S., \& Asha, A. (2016). Study of Genetical Diversity of Mahseer (Tor Tor) from Rana Pratap Sagar Dam, Kota (Rajasthan) India. International Journal of Applied and Natural Sciences (IJANS) ISSN (P), 2319-4014.

36. Laghetti, G. Piergiovanni, AR. Sonnante, G.Lioi, L. and Pignone, D. (2008).The Italian lentil genetic resources, a worthy basic tool for breeders.Eur. J. Plant Sci. Biotechnol. 2: 48-59.

37. Lev-Yadun, S. Gopher, A. and Abbo, S. (2000). The cradle of agriculture.Science. 288: 1602-1603.

38. Madina, MH. Haque, ME. Dutta, AK. Islam, MA. Deb, AC. And Sikdar, B. (2013).Estimation of genetic diversity in six lentil (Lens culinarisMedik.) varieties using morphological and biochemical markers.International Journal of Scientific and Engineering Research.4 (9).

39. Ministry of Health.(2000). Survey on anemia in Morocco. Available on line at www.sante.org.ma

40. Nei, M. (1973). Analysis of gene diversity in subdivided population. Proceeding of the national academy of sciences. USA. 70 (12): 3321-3323.

41. Oomah, B.D. Caspar, F.Malcolmson, L.J.Bellido, A.S.(2011).Phenolics and antioxidant activity of lentil and pea hulls. Food Res Int. 44:436-441 
42. Peakall, R. and Smouse, PE.(2006). GENALEX 6: Genetic analysis in Excel. Population genetic software for teaching and research. Molecular Ecology. 6: 288-295.

43. Petranovic, D.Batinac, T.Petranovic, D.Ruzic, A.Ruzic, T.(2008).Iron deficiency anemia influences cognitive functions. Med Hypotheses. 70: 70-2.

44. Piergiovanni, AR. and Taranto, G. (2003). Geographic distribution of genetic variation in a lentil collection as revealed by SDS-PAGE fractionation of seed storage proteins. Journal of Genetics and Breeding. 57 (1): 39-46.

45. Prafull, K. Trivedi, A. Adarsh, A. Verma, R. Rajesh, K. Vyas, RP. and Yadav, M.K. (2018). Genetic characterization of lentil genotypes based on SDS-PAGE. Journal of Pharmacognosy and Phytochemistry. 7(1): 274-278.

46. Rehman, ZU. Rashid, M. and Shah, WH. (2004).Insoluble dietary fiber components of food legumes as affected by soaking and cooking processes.Food Chemistry. 85: 245-249.

47. Ryan, E. Galvin, K. O'Connor, T.P. Maguire, A.R. O'Brien, N.M. (2007). Phytosterol, squalene, tocopherol content and fatty acid profile of selected seeds, grains, and legumes. Plant Foods for Human Nutrition. 62:85-91.

48. Sarker, A. Rizvi, A. H. and Singh, M. (2017).Genetic variability for nutritional quality in Lentil (Lens culinarisMedikus Subsp. culinaris).Legume Research. DOI: 10.18805/LR-372.

49. Scippa, GS. Rocco, M. Lalicicco, M. Trupiano, D. Viscosi, V. Di Michele, M. Arena, S. Chiatante, D. and Scaloni, A. (2010). The proteome of lentil (Lens culinarisMedik.) seeds: discriminating between landraces. Electrophoresis. 31: 497-506.

50. Shannon, CE. and Weaver, W. (1949). The Mathematical Theory of Communication.University of Illinois. Urbana. Chicago. IL, USA. 3-24.

51. Simopoulos, A.P. (2008). The importance of the Omega-6/Omega-3 fatty acid ratio in cardiovascular disease and other chronic diseases.Experimental Biology and Medicine (Maywood). 233(6): 674-688.

52. Simopoulos, A.P. (2010). Genetic variants in the metabolism of omega-6 and omega-3 fatty acids: their role in the determination of nutritional requirements and chronic disease risk. ExpBiol Med. 235(7):785-95.

53. Sultana, T. Ghafoor, A. and Ashraf, M. (2006). Geographic pattern of diversity of cultivated lentil germplasm collected from Pakistan assessed by protein assays. ActaBiologicaCracoviensia.Series Botanica. Poland 48: 77-84.

54. Vieteri F.E. (1994).The consequences of iron deficiency and anemia in pregnancy on maternal health, the fates and the infant.ACC/SCN.News.11: 14618.

55. Kumari, S. S., Srihari, D., Shankar, C. R., Reddy, V. C., \& Sanker, A. S. (2014). Genetic divergence and combining ability studies for exploitation of heterosis in paprika (Capsicum annuum L). International Journal of Agricultural Science and Research (IJASR), 4(2), 59-66.

56. Wang, N. Hatcher, D.W.ToewsR. and Gawalko E.J.(2009). Influence of cooking and dehuling on nutritional composition of several varieties of lentils (Lens culinaris).LWT- Food Science and Technology. 42: 842-848.

57. Welch, R.M., Graham, R.D. (2004). Breeding for micronutrients in staple food crops from a human nutrition perspective. J Exp Bot. 55(396):353-64.

58. White, P.J.Broadley MR (2005) Bio-fortifying crops with essential mineral elements. Trends Plant Sci. 10:586-593.

59. White, P.J.and Broadley, M.R.(2009).Bio-fortification of crops with seven mineral elements often lacking in human diets iron, zinc, copper, calcium, magnesium, selenium and iodine.New Phytol. 182:49-84. 
60. Yang, X. E. Chen, W. R. and Feng, Y. (2007).Improving human micronutrient nutrition through bio-fortification in the soil plant system: China as a case study. Environmental Geochemistry and Health. vol. 29, 5: 413-428.

61. Zaccardelli, M. Lupo, F. Piergiovanni, AR. Laghetti, G. Sonnante, G. Daminati, MG. Sparvoli, F. and Lioi, L. (2011). Characterization of Italian lentil (Lens culinarisMedik.) germplasm by agronomic traits, biochemical and molecular markers. Genetic Resources and Crop Evolution. 59: 727-738.

62. Zia-UL-Haq, M. Ahmad, S. Aslam Shad, M. Iqbal, S. Qayum, M. Ahmad, A.Luthria, D. L. and Amarowicz R. (2011). Compositional studies of lentil (Lens culinaris MEDIK.) cultivars commonly grown in Pakistan. Pak. J. Bot. 43(3): $1563-1567$.

63. Zohary, D. (1972). The wild progenitor and place of origin of the cultivated lentil Lens culinaris. Economic Botany. 26:326332. 
